\title{
BUSINESS AND TRANSLATION AS POWER GAMES: THE AUTOMOTIVE INDUSTRY IN BRAZIL
}

\author{
Jean-François Brunelière* \\ Universidade Federal do Rio Grande do Norte
}

\begin{abstract}
Corporate translation represents a real paradox for Translation Studies (TS): while the discipline's academic institutionalization and the origins of many translation training centres are heavily indebted to the globalization movement, fundamental research on communication in the economic pulse of this movement is still underdeveloped. The various impacts (in terms of economy, manpower and prestige) of international operations, which largely depend on multilingualism and translation, represent an excellent motivation for studying multinational companies' behaviour, especially at the intersection of language and power. With this in mind, the present article focuses on PSA Peugeot Citroën's activity in the Brazilian market in the expectation that the character of its power structure will be revealed in its external communication. A descriptive methodology was used to analyse all 2013 press releases on its Brazilian corporate website, in comparison with those on Argentinian and International sites, to determine how questions of power can explain textual shifts. The analysis demonstrates the extent of Brazilian publishing autonomy and the subsidiary's relationships with other corporate divisions. This case study can be considered an illustration of how corporate translation can quickly lead to core issues within TS.
\end{abstract}

Keywords: Descriptive Translation Studies. Power. Multinational Companies.

\footnotetext{
* Possui graduação (licenciatura e bacharelado) em Letras Francês pela Universidade Federal de Santa Catarina (2016) e doutorado em Estudos da Tradução pela Universidade Federal de Santa Catarina (2016). Tem experiência na área de ensino de língua francesa no Brasil. Trabalha ocasionalmente com tradução no Brasil. Atualmente é professor Assistente na Universidade Federal do Rio Grande do Norte, onde atua na área de Didática e ensino de língua francesa. E-mail: jfbruneliere.traducao@gmail.com
} 


\section{ENTREPRISES ET TRADUCTION À L'ÉGARDE JEUX: L'INDUSTRIE AUTOMOBILE AU BRÉSIL}

Résumé: La traduction réalisée par les entreprises représente un paradoxe pour la traductologie : alors que l'institutionnalisation académique de la discipline et les origines des centres de traduction doivent beaucoup au mouvement de mondialisation, la recherche fondamentale en communication économique y est toujours sous-développée. L'importance des impacts (en termes économiques, d'emploi et de prestige) des opérations internationales, qui dépendent éminemment du multilinguisme et de la traduction, nous incite à étudier le comportement des entreprises multinationales, et en particulier la dynamique entre langues et pouvoir. Cet article traite de l'activité de PSA Peugeot Citroën au Brésil et entend révéler certaines de ses structures de pouvoir via l'analyse de sa communication externe. Des méthodes descriptives sont utilisées pour analyser les communiqués de presse présentés par PSA sur son site Internet brésilien en 2013, en les rapprochant des communiqués des sites argentins et international et en cherchant à déterminer en quoi des questions de pouvoir pourraient expliquer certaines modifications textuelles. L'analyse démontre l'autonomie éditoriale de la filiale brésilienne de l'entreprise, ainsi que le type de relation qu'elle noue avec d'autres filiales. Cette étude de cas illustre la manière dont la traduction dans les entreprises mène rapidement à des questions clés pour la traductologie.

Mots-clés: Etudes Descriptives de la Traduction. Pouvoir. Entreprises Multinationales.

\section{NEGÓCIOS E TRADUÇÃO COMO JOGOS DE PODER: A INDÚSTRIA AUTOMOBILÍSTICA NO BRASIL}

Resumo: A tradução realizada pelas empresas representa um paradoxo para os Estudos da Tradução. Embora a institucionalização acadêmica da disciplina e a origem de muitos centros de treinamento de tradutores estejam claramente relacionados ao movimento de globalização, a pesquisa fundamental sobre a comunicação na área econômica continua pouco desenvolvida. As múltiplas consequências (em termos econômicos, de mão de obra e de prestigio) das operações internacionais, amplamente dependentes do multilinguismo e da tradução, constituem excelentes motivos para estudar o comportamento das empresas multinacionais, prin- 
cipalmente quando questões de língua e de poder se encontram. Assim, este artigo retrata a atividade da PSA Peugeot Citroën no mercado brasileiro, procurando verificar como sua estrutura de poder transparece na sua comunicação externa. Por meio de métodos descritivos, analisamos os comunicados de imprensa publicados no site corporativo brasileiro em 2013, comparando-os com aqueles publicados nos sites argentino e internacional, no intuito de verificar em que medida questões de poder podem explicar modificações textuais. A análise demonstra a autonomia da filial brasileira e as relações que constrói com outros setores da empresa. Esse estudo de caso pode ser considerado uma ilustração da maneira como a tradução nas empresas leva rapidamente a temáticas essenciais para os Estudos da Tradução.

Palavras-chaves: Estudos Descritivos da Tradução. Poder. Empresas Multinacionais.

\section{Introduction}

In spite of the clear link between the remarkable globalization movement following World War II (at economic, cultural and political levels) and the subsequent development of translation training centres around the world, we have to admit that, since Translation Studies (TS) established itself as a discipline (HOLMES 1972, was a key moment), business translation has not been an important topic in its research programs. Nevertheless, for those interested in studying the relationship between translation and questions of power, an analysis of translated communication in multinational companies (MNCs) could prove useful.

After reviewing the results of related studies, which serve as a starting point for our own reflection, we discuss the potential Descriptive Translation Studies (DTS) methodologies for analysing business texts, and then present an analysis of press releases produced by PSA Peugeot Citroën, a French automotive manufacturer, in order to illustrate certain dynamics of power within the MNC in Brazil. This market, which might have been considered peripheral two decades ago, is now fully integrated to the globalized network. This recent change of dynamics regarding 
the so-called BRICS coalition makes Brazil a particularly valuable object of study.

\section{Cross-border News and Power Issues}

Among disciplines that analyse the business world, Organization Studies (OS) deserves special attention, since a number of recent OS studies have dealt with language(s) and translation. Logemann and Piekkari (2015), for instance, argue that the power relationship between headquarters and subsidiaries shifts over time, with translation used in different ways until a form of "company speak" (or idiolect) finally appears $(2015,46)$. They further demonstrate that a subsidiary manager's translation of the CEO's letters can be a means of resisting headquarters control in that the manager/translator "made an effort to render the president's letters more sensitive to locally important matters" (LOGEMANN \& PIEKKARI 2015, 41). This "extreme localization" tendency may sound familiar to some TS scholars. It is very similar to what has already been observed in news translation, an area where the localization concept (imported from the software business) has now been used for many years (PYM 2004; ORENGO 2005). For instance, Kang (2007) states that "the original text is made subordinate to the journalistic purpose of recontextualization" (2007, 221). The very selection of topics, and thus of texts to be translated, depends on "someone's" (probably not an individual translator's) choices. Furthermore, cultural aspects influence such choices. According to Van Doorslear, the "world news coverage and selection ['transediting' process is] informed by existing national and cultural stereotypes" (2012, 1057). Thus, certain types of news stories seem more prevalent in certain countries. But to what extent does this apply to news produced by MNCs for release in different markets? This is what we aim to find out, by an analysis of texts that PSA Peugeot Citroën, a French automotive 
manufacturer, released on three versions of its corporate website (Brazilian, Argentinean and International).

This could serve as a good opportunity for TS to introduce MNC communication of MNCs in the TS agenda (which claims to be interdisciplinary), and offer new insights about real-world practice to other disciplines that are already working on globalization, international trade and organizations. But one of our first tasks will be, as far as the methodology is concerned, to opt for one of the many approaches available within TS. Our interest for power issues may influence our choice at that point.

\title{
2. From Norms and Power to Research on Organization
}

Power is intimately connected with translation, through the concept of norms. The use of norms had already gained wide currency within sociology for a number of years before Gideon Toury, who can be considered as the main architect of the norms concept within TS, defined them as "a category for descriptive analysis of translation phenomena" $(1978,91)$. In sociological traditions, norms are considered a manifestation of power relationships within societies. Translation scholar Theo Hermans confirms this for TS when he states that:

\begin{abstract}
Given the nature of translation and of Translation studies, an approach through these concepts [rules and conventions] may well be productive, especially if we wish to focus on the social dimension of translating and on the place of translation in relation to power and ideology. (HERMANS 1996, 26.
\end{abstract}

The robust methodology developed in Descriptive Translation Studies should prove valuable for approaching power issues through this corpus. We shall alternate between macro-level and 
micro-level analyses, in order to identify regularities in (1) the "choice of [...] individual texts to be imported through translation" (TOURY 1995, 58), which are an indication of the "preliminary norms", then (2) analysis of the "degree of fullness of the translation" (idem) and the "textual-linguistic norms" at work, which constitute the "operational norms". Through this analysis, the nature of power relationships between the Brazilian subsidiary and others PSA Peugeot Citroën's entities should become more evident and, beyond linguistic considerations, lead us directly to organizational issues within the MNC. But before describing the corpus, a few words about the company and its organization might bring the greater context of the study into focus.

\section{PSA Peugeot Citroën, Brazil and Language(s)}

In 2011, PSA Peugeot Citroën, a car manufacturer with French origins, was the $7^{\text {th }}$ ranked car manufacturer in the world with 3,161,955 cars produced (OICA, 2012), selling points in 160 countries and twelve assembly plants in six countries - including Brazil since 2001. At PSA Peugeot Citroën, it is worth noting that languages and the use of translation have undergone some changes over the years. In 2010, the corporate language was changed from French to English at the management level, with a simple explanation: "As the Group takes on an increasingly international profile, more non-French members will join the management teams and English will become the day-to-day working language" (PSAa 2011, 168). Another spectacular change in terms of languages can be deduced from the corporate site, which changed from French and English to French, English and Spanish in 2002, and then reverted to French and English as recently as 2012. All these indications about the company's language and translation policies reveal fluctuations and struggles involving different dynamics, depending on the level (i.e. management vs. operators, employees vs. clients). The analysis of a specific segment of PSA's external 
communication may be an opportunity to discover more about the relationship between translation and power in this company and, more generally, in MNCs.

\subsection{PSA Press Releases on the Brazilian Corporate Website: power relations at work}

One of the privileged channels towards the international cooperation within PSA Peugeot Citroën is its entire system of websites. Let us notice here the complexly structured network: 27 websites are listed on http://www.psa-peugeot-citroen.com/en/ content/all-sites, but a few of them, the "commercial" ones, for example (www.peugeot.com or www.citroen.com), give access to dozens of others - basically one per country, in fact one per market, involved.

Our article focuses on the Brazilian press releases, which can be found on the PSA Peugeot Citroën Brazilian corporate website ${ }^{1}$ (www.psa-peugeot-citroen.com.br), in the "news and videos" (novidades e vídeos) page.

Although the Brazilian website provides access to Brazilian press releases, for comparison, the content of two other PSA websites will be included: Argentina (constructed on the same model as Brazil, but with press releases in Spanish) and the international site (a different model, with press releases in both French and English). The Brazilian website does not hide the existence of these sites, but instead provides direct links to them through special icons. We shall visit these two sites to understand how the Brazilian press releases compare to the others.

To generate a representative sample, we select a complete year: 2013. Based on the Brazilian website, we look for possible connections between press releases and evidence of power relationships (through translation) between the Brazilian, the

${ }^{1}$ For simplicity's sake, website will indicate "corporate website" in the rest of the article. This study only considers PSA's corporate websites, excluding all other types (commercial websites, etc.).

Cad. Trad., Florianópolis, v. 37, no 3, p. 185-213, set-dez 2017 
Argentinian and the international websites. Another of our questions is to what extent the general approach to distribution is a matter of localization, as suggested by Pym (2004), Orengo (2005) and Van Doorslaer (2012) in the case of news releases.

The first step of our analysis consists of listing all the news documents released in 2013 on the Brazilian website: a total of 33 documents, listed from D1 to D33 (Table 1). In this table, a distinction is drawn between specifically 'national' documents and those that can be shared by different websites. We use AR, BR, EN and FR (from now on) in order to refer to the particular document in Spanish on the Argentinian website, Portuguese on the Brazilian website and English and French on the international website. For instance, D8 AR is the Argentinian document corresponding to the Brazilian document 8 .

Table 1. All 2013 press releases from the Brazilian PSA website

\begin{tabular}{|l|l|l|l|}
\hline $\begin{array}{l}\text { Document } \\
\text { number }\end{array}$ & Released & Subject & $\begin{array}{l}\text { Other } \\
\text { parallel } \\
\text { documents? }\end{array}$ \\
\hline D1 & $01 / 01 / 13$ & New engine launched & No \\
\hline D2 & $01 / 01 / 13$ & $\begin{array}{l}\text { Painting unit in Porto Real (Brazil) } \\
\text { plant }\end{array}$ & No \\
\hline D3 & $01 / 01 / 13$ & $\begin{array}{l}\text { One-millionth vehicle produced in } \\
\text { Brazil }\end{array}$ & No \\
\hline D4 & $01 / 01 / 13$ & Presentation of PSA in Brazil & No \\
\hline D5 & $01 / 01 / 13$ & $\begin{array}{l}\text { Sheet metal unit in Porto Real } \\
\text { (Brazil) plant }\end{array}$ & No \\
\hline D6 & $01 / 01 / 13$ & $\begin{array}{l}\text { Assembly unit in Porto Real (Brazil) } \\
\text { plant }\end{array}$ & No \\
\hline D7 & $01 / 01 / 13$ & 208 production launched in Brazil & No \\
\hline D8 & $10 / 01 / 13$ & PSA 2012 commercial results & FR/EN/AR \\
\hline D9 & $20 / 01 / 13$ & $\begin{array}{l}\text { PSA, Argentina's leading car } \\
\text { manufacturer }\end{array}$ & AR \\
\hline D10 & $30 / 01 / 13$ & Launch of 208 production in Brazil & FR/EN/AR \\
\hline D11 & $30 / 01 / 13$ & 10 years of the Brazilian engine plant & No \\
\hline D12 & $02 / 04 / 13$ & Suppliers' awards Latin America & AR \\
\hline D13 & $08 / 04 / 13$ & PSA, France's leading patent filer & FR/EN/AR \\
\hline
\end{tabular}




\begin{tabular}{|c|c|c|c|}
\hline D14 & $24 / 04 / 13$ & PSA's first quarter 2013 revenues & FR/EN/AR \\
\hline D15 & $27 / 04 / 13$ & $\begin{array}{l}\text { Partnership with an educational } \\
\text { institute in Brazil }\end{array}$ & No \\
\hline D16 & $15 / 05 / 13$ & $\begin{array}{l}\text { Students welcomed for training in } \\
\text { PSA's plant in Brazil }\end{array}$ & No \\
\hline D17 & $03 / 06 / 13$ & $\begin{array}{l}\text { PSA gives computers to an } \\
\text { association in Brazil }\end{array}$ & No \\
\hline D18 & $05 / 06 / 13$ & $\begin{array}{l}\text { A PSA petrol engine wins } \\
\text { international award }\end{array}$ & FR/EN/AR \\
\hline D19 & $12 / 06 / 13$ & $\begin{array}{l}\text { A } 208 \text { with all Brazilian employees' } \\
\text { signatures }\end{array}$ & No \\
\hline D20 & $14 / 06 / 13$ & $\begin{array}{l}\text { Three European awards for PSA's } \\
\text { hybrid air technology }\end{array}$ & FR/EN/AR \\
\hline D21 & $19 / 06 / 13$ & $\begin{array}{l}\text { PSA announces record sales in } \\
\text { Argentina }\end{array}$ & FR/EN/AR \\
\hline D22 & $28 / 06 / 13$ & $\begin{array}{l}\text { PSA delivers } 139 \text { light commercial } \\
\text { vehicles to Brazilian Justice } \\
\text { Department }\end{array}$ & No \\
\hline D23 & $03 / 07 / 13$ & PSA's $3^{\text {rd }}$ plant in China & FR/EN \\
\hline D24 & $11 / 07 / 13$ & PSA's first half 2013 results & FR/EN/AR \\
\hline D25 & $22 / 08 / 13$ & $\begin{array}{l}\text { PSA offers tennis lessons to young } \\
\text { Brazilians }\end{array}$ & No \\
\hline D26 & $29 / 08 / 13$ & $\begin{array}{l}\text { PSA participate in a congress about } \\
\text { diesel in Brazil }\end{array}$ & No \\
\hline D27 & $05 / 09 / 13$ & $\begin{array}{l}\text { PSA, number one exporter from Rio } \\
\text { de Janeiro to Mercosul market }\end{array}$ & No \\
\hline D28 & $10 / 10 / 13$ & $\begin{array}{l}\text { Partnership between PSA and a } \\
\text { Brazilian institute for researches } \\
\end{array}$ & No \\
\hline D29 & $17 / 10 / 13$ & $\begin{array}{l}\text { Exposition about mobility in Sao } \\
\text { Paulo }\end{array}$ & AR \\
\hline D30 & $18 / 10 / 13$ & $\begin{array}{l}\text { First presentation of the hybrid air } \\
\text { technology in Sao Paulo }\end{array}$ & AR \\
\hline D31 & $25 / 11 / 13$ & New president of PSA & FR/EN/AR \\
\hline D32 & $26 / 11 / 13$ & $\begin{array}{l}\text { PSA gives computers to an } \\
\text { association in Brazil }\end{array}$ & No \\
\hline D33 & $27 / 11 / 13$ & $\begin{array}{l}\text { Partnership between PSA and a Rio } \\
\text { de Janeiro university for research on } \\
\text { engines }\end{array}$ & No \\
\hline
\end{tabular}


It is tempting to immediately begin analysing the relationships between these various texts. However, an initial "panoramic view" of each site, and of its general "editorial" politics might provide us with a better understanding of the deep communication tendencies of each market.

\subsection{Different global scopes}

While 33 documents were published on the news section of the Brazilian PSA website in 2013, 60 documents were published on the Argentinian website and 109 on the international one. Although the international website's press releases are texts only, the SouthAmerican ones are often texts plus image(s) or sometimes videos (8 in Brazil, 9 in Argentina).

A categorization of the news released on the three websites might help us to understand how they function. Nine thematic categories are sufficient to roughly describe all the news: (1) Industrial (plants and production); (2) Awards (whether won or awarded by PSA); (3) Results (sales or financial results directly linked with sales); (4) Strategic (new CEO or Board members); (5) Philanthropic projects; (6) Employees (nominations/interviews/training, labour union agreements, etc.), (7) Research (new technology launches, cooperation with universities, etc.), (8) Financial and (9) Commercial (vehicle launches, motor shows, etc.).

Since focusing on a specific geographic area might also be of interest, the geographic location of press-release's content is noted, distinguishing between: (1) the world (if the news concerns the company as a whole, or a product/process which is not restricted to specific markets), (2) Brazil, (3) Argentina, (4) one particular country/market, (5) Europe or (6) South-America. The results of this categorization can be found in Table 2 (thematic scope), and Table 3 (geographic scope). 
Table 2. Thematic scope of the press releases observed.

\begin{tabular}{|l|l|l|l|l|l|l|}
\hline & \multicolumn{3}{|l|}{ FR/EN } & \multicolumn{2}{l|}{ BR } & AR \\
\hline & Quantity & $\%$ & Quantity & $\%$ & Quantity & $\%$ \\
\hline Industrial & 9 & $8.3 \%$ & 12 & $36.4 \%$ & 7 & $11.7 \%$ \\
\hline Awards & 7 & $6.4 \%$ & 4 & $12.1 \%$ & 8 & $13.3 \%$ \\
\hline Results & 11 & $10.1 \%$ & 6 & $18.2 \%$ & 4 & $6.7 \%$ \\
\hline Strategic & 13 & $11.9 \%$ & 1 & $3.0 \%$ & 7 & $11.7 \%$ \\
\hline Philanthropic & 0 & $0.0 \%$ & 3 & $9.1 \%$ & 15 & $25.0 \%$ \\
\hline Employees & 31 & $28.4 \%$ & 3 & $9.1 \%$ & 6 & $10.0 \%$ \\
\hline Research & 9 & $8.3 \%$ & 4 & $12.1 \%$ & 7 & $11.7 \%$ \\
\hline Financial & 28 & $25.7 \%$ & 0 & $0.0 \%$ & 3 & $5.0 \%$ \\
\hline Commercial & 1 & $0.9 \%$ & 0 & $0.0 \%$ & 3 & $5.0 \%$ \\
\hline Total & 109 & $100.0 \%$ & 33 & $100.0 \%$ & 60 & $100.0 \%$ \\
\hline
\end{tabular}

Table 3. Geographic scope of the press releases observed.

\begin{tabular}{|l|l|l|l|l|l|l|}
\hline & \multicolumn{2}{|l|}{ FR/EN } & BR & AR \\
\hline & Quantity & $\%$ & Quantity & $\%$ & Quantity & $\%$ \\
\hline World & 75 & $68.8 \%$ & 5 & $15.2 \%$ & 19 & $31.7 \%$ \\
\hline Brazil & 1 & $0.9 \%$ & 22 & $66.7 \%$ & 2 & $3.3 \%$ \\
\hline Argentina & 1 & $0.9 \%$ & 2 & $6.1 \%$ & 26 & $43.3 \%$ \\
\hline $\begin{array}{l}\text { One particular } \\
\text { country }\end{array}$ & 11 & $10.1 \%$ & 2 & $6.1 \%$ & 6 & $10.0 \%$ \\
\hline Europe & 21 & $19.3 \%$ & 1 & $3.0 \%$ & 1 & $1.7 \%$ \\
\hline Latin America & 0 & $0.0 \%$ & 1 & $3.0 \%$ & 6 & $10.0 \%$ \\
\hline Total & 109 & $100.0 \%$ & 33 & $100.0 \%$ & 60 & $100.0 \%$ \\
\hline
\end{tabular}

Two-thirds of the Brazilian press releases (and nearly half of the Argentinian ones) deal with local information. "Low-strategic level" news (charity and awards) is prominent, while financial news is scarce. Most Brazilian "Industrial" releases (8 of 12) are videos of specific sectors in a local plant. All together, these first 
- very general - observations already demonstrate that PSA did not choose to homogenise the scope of its news communication worldwide. The subsidiary seems to insist on local information, while the international press releases are much more strategic in scope. The local-oriented view in South America would drive any curious Brazilians or Argentinians seeking a better global understanding of the company's to the international website or other foreign source. Although 2013 was a difficult year for PSA, as can be understood through the multiple international releases dealing with financial issues (loans, the French State guarantee on PSA's debt, bond issues, etc.), these topics do not seem worthy of mention in Brazil. Moreover, many "Employee" themes in the European sector (e.g. the "social contract" as a means of reducing the European workforce) are fully ignored in Brazil. The Brazilian audience is informed more about partnerships with local universities and training centres than about, for instance, the worldwide strategic alliance with General Motors. It could well be that the company, in concert with the geographical distance, is making use of its different regional identities (and media networks) to "protect" its image in South America. However, is this astute use of Internet segmentation by the subsidiaries or something decided at headquarters? Although information from such a macro-level could not be obtained from the corpus, it would seem reasonable to suspect that the translation process is indeed used to occlude certain facts and promote others.

The difference in focus between Brazilian and Argentinian press releases is a demonstration of the autonomy of these subsidiaries. However, despite the local power detectable in the macro-level of analysis, a closer look at texts is needed if we want to go further in our understanding of the company's use of its corporate websites.

In our search for particular communication streams (i.e. where particular documents come from and where, how they are distributed, on the basis of what kind of options and involving what kind of power games), we shall study (1) texts that can be found on the Brazilian website only, (2) texts released both on the 
Brazilian and the Argentinian websites and (3) texts that are also released on the international website of the company. No need to stress that certain situations, texts and images are obviously international without necessarily being "global" - which would mean, in our case: interesting from the perspective of all the "national" websites involved.

\subsubsection{Brazilian only}

Of the items in our sample, eight are videos (D1 to D7 and D11) and the rest are texts. The videos can be considered as "local" documents, since they always deal with the Brazilian plant or "Brazilian" events (e.g. one-millionth vehicle produced in Brazil). These videos are, for the most part, images only, with very few textual elements, and have no relationship with other documents available elsewhere. Therefore, they will not be analysed together with the twenty-five other textual documents, about which much more can be said.

For eleven of the press releases on the Brazilian website (44\% of total texts), there is no equivalent document on any of the other websites. At the end of each of these documents, without exception, the same short standard text, describing PSA's activities in $\mathrm{Brazil}^{2}$, is used as a kind of copyright signature. At first sight, the "Brazilian only" press releases do not provide us with really strategic information; they are not central in the company's global communication. Their function rather seems to be symbolic: giving a local flavour to the Brazilian corporate website. As far as Brazilian independence on the overall website is concerned, there can be no doubt: though the obvious interaction with European sources remains visible, the Brazilian managers have kind of a "private corner" of the website in their own hands. How it is negotiated with the headquarters and to what extent it tells us more about

${ }^{2}$ Brazilian "signature" text: A PSA Peugeot Citroën no Brasil [...] presente industrialmente no país desde 2001 [...] possui mais de 5.000 colaboradores efetivos no país.

Cad. Trad., Florianópolis, v. 37, n⿳ 3, p. 185-213, set-dez 2017 
participation in decision-making cannot be deduced without greater insight into the overall PSA Internet management system. And, of course, Internet management (translation included) functions merely as an indicator of larger power relationships.

\subsubsection{Brazilian-Argentinian (or Brazilian and Argentinian)}

In 2013 , four press releases (16\% of all texts) are parallel on the Brazilian and the Argentinian websites. They deal with events, occurring either in Brazil or in Argentina that are not global in scope. In D12 (about "Latin America suppliers" awards), both countries are directly involved, but the release might also deal with a more local fact (such as the exposition happening in one of the two countries only, for instance), recognized as important by the neighbouring country (as in D9, D29 and D30).

Before even trying to identify which document is "the original", our observation is that the verbal formulation in both languages is so parallel in terms of syntax and lexicon that the reader suspects that one is the model of the other. Was their production simultaneous? Was the French partner monitoring this production? Although it is difficult to make categorical statements based solely on this corpus, the fact is that any parallel text production would necessarily involve coordination between the subsidiaries. However, to create and maintain such cooperation some kind of pressures is necessary, since it would seem that each subsidiary would tend to develop its own discourse: therefore these parallel texts are, in themselves, evidence of power relations within the company.

\subsubsection{In-house competition?}

There is, nevertheless, no doubt about divergent options in the Brazilian/Argentinian approach. Several intentional deletions could be interpreted as evidence of competition between Argentinian and Brazilian subsidiaries. In D29, the entire sentence "Con un promedio de un lanzamiento anual desde 2004, en 2014 PSA 
continuará su apuesta a la producción en el país con la presentación de un nuevo vehículo que será fabricado en la planta de El Palomar" promises a bright future for Argentina in the AR text, with PSA in the role of supporter of the local economy, but this is entirely missing in the BR version. Neither Argentinians nor Brazilians have the monopoly of this type of behaviour, as D12 exemplifies (Table 4).

Table 4. Information deleted in Argentinian PSA 2013 press release D12.

\begin{tabular}{|l|l|}
\hline AR & $\begin{array}{l}\text { Tenemos por objetivo crecer con calidad e innovación en América } \\
\text { Latina }\end{array}$ \\
\hline $\mathbf{B R}$ & $\begin{array}{l}\text { Temos o objetivo de crescer com qualidade e inovação no Brasil e na } \\
\text { América Latina }\end{array}$ \\
\hline $\mathbf{A R}$ & $\begin{array}{l}\text { logramos producir y lanzar automóviles modernos e innovadores en el } \\
\text { mercado regional }\end{array}$ \\
\hline $\mathbf{B R}$ & $\begin{array}{l}\text { estamos conseguindo produzir e lançar automóveis modernos e } \\
\text { inovadores no mercado nacional, como o Novo Citroën C3 e o Peugeot } \\
\text { 208, que começa a ser vendido no país nos próximos dias }\end{array}$ \\
\hline
\end{tabular}

Let us remember that PSA has plants in Argentina and Brazil, but each new vehicle production "offered" to one plant automatically has local effects in terms of jobs and corporate image, which is seen as a "national" manufacturer. When given translations respect their text model from the beginning to the end in terms of syntax, lexicon, register, while suddenly deleting one full sentence, it is clear that principles other than language alone are at stake. No doubt this is a matter of higher-level decision-making, as Pym observes (2004, xi), when saying: "explicit deletion and addition mostly require an authority external to the translating translator". In this situation, language and discourse seem to be in the hands of Argentinian/Brazilian managers, maybe with the authorization of the headquarters. 
Linguistic "fidelity" to textual and discursive features contrasting with the merciless deletion of others: it is a matter of power. It seems actually that any kind of descriptive research, whether small or large scale confirms such heterogeneities.

\subsubsection{Who are the actors, really?}

One of the grey areas in such situations, and in the explanatory part of our cultural-empirical research, is the lack of access to information partly hidden behind the curtain. Who exactly is translating, then revising, who decides about dissemination, when do French - or other - decision makers interfere with their Brazilian colleagues, if at all?

It seems obvious that two different actors play a role: a 'linguistic' translator first, then a 'censor-reviser'. But this formulation is too narrow since, especially in international business, it is very naive to imagine that only two individual people are involved: in our contemporary society translators are integrated into the (collective) corporate production of discourse (see PIEKKARI et al. 2013).

\subsubsection{Text origins}

In fact, our questions about directionality (which language/ source provides the message to the partner from the other country?) should become simpler from the moment we can establish who is publishing first. Hence, chronological observation of our releases shall be helpful. D9, dealing with sales in Argentina, was available on the Brazilian website eleven days after being posted on the Argentinian site. The other three texts were available on the Brazilian website first, then on the Argentinian one (up to five days later).

A second type of evidence about textual origin is the small "signature" paragraph produced at the end of the "genuine" Brazilian texts, available in all texts except the one referring to sales in Argentina. The two types of evidence, once combined, 
indicate the origin of the texts, except in case there would be one common original text.

In an attempt to find out about general and recurrent tendencies, we could say that the Argentinian and Brazilian websites share texts when regional events occur in Latin America, with text creation priority going to the event-hosting country, and translation being used by the other, including leeway to hide certain elements (especially the success of its neighbour, if the event does not serve as a simple example of the company's well-being and implies comparison between countries' industrial performances).

\subsubsection{Brazilian, international, Argentinian}

In 2013, ten texts (40\% of total texts) are parallel on the Brazilian and international PSA websites (bearing in mind that the international site is always available in both French and English). Nine of these texts are also parallel with texts released on the Argentinian site.

These texts deal with two main types of events. The first ones could be called "real international events" (D8, D13, D14, D18, D20, D24 and D31). There is no reason why Brazil would be in charge of the dissemination of such announcements. The second type could be called "local events with general (even if only symbolic) significance for every country in which PSA is present" (D10, D21, D23). In this case, the "authorship" of the initial text may be local, for a later global distribution, or the text could have been written in collaboration between local and global levels of the company. Other clues must to be discovered by specific methods.

By means of a methodology that moves sequentially from macro data (place and date of publication) to micro data (textual structure and textual items), it is possible to detect the principles underlying the main choices in Brazilian texts. 


\subsubsection{First international, then Brazilian/Argentinian}

A first observation at the macro level, basic but often illuminating, is the exact date of the release (Table 5).

Table 5. Simultaneous and linear vs. capricious chronology in the distribution?

\begin{tabular}{|c|c|c|c|c|}
\hline \multirow[b]{2}{*}{ Document } & \multirow[b]{2}{*}{ Object } & \multicolumn{3}{|c|}{ Date of release } \\
\hline & & $\begin{array}{l}\text { FR/EN } \\
\text { (same date } \\
\text { for the two } \\
\text { languages) }\end{array}$ & $\begin{array}{l}\mathrm{BR} \text { (+ delay } \\
\text { compared to FR/ } \\
\mathrm{EN})\end{array}$ & $\begin{array}{l}\mathrm{AR}(+ \text { delay } \\
\text { compared to BR) }\end{array}$ \\
\hline D8 & $\begin{array}{l}\text { PSA } 2012 \\
\text { commercial } \\
\text { results }\end{array}$ & $09 / 01 / 13$ & $10 / 01 / 13(+1)$ & $10 / 01 / 13(0)$ \\
\hline D10 & $\begin{array}{l}\text { Launch of } 208 \\
\text { production in } \\
\text { Brazil }\end{array}$ & $30 / 01 / 13$ & $30 / 01 / 13(0)$ & $30 / 01 / 13(0)$ \\
\hline D13 & $\begin{array}{l}\text { PSA, France's } \\
\text { leading patent } \\
\text { filer }\end{array}$ & $05 / 04 / 13$ & $08 / 04 / 13(+3)$ & $05 / 04 / 13(-3)$ \\
\hline D14 & $\begin{array}{l}\text { PSA first quarter } \\
2013 \text { revenues }\end{array}$ & $24 / 04 / 13$ & $24 / 04 / 13(0)$ & $24 / 04 / 13(0)$ \\
\hline D18 & $\begin{array}{l}\text { A PSA petrol } \\
\text { engine wins an } \\
\text { international } \\
\text { award }\end{array}$ & $05 / 06 / 13$ & $05 / 06 / 13(0)$ & $10 / 06 / 13(+5)$ \\
\hline D20 & $\begin{array}{l}\text { Three European } \\
\text { awards for } \\
\text { PSA's hybrid air } \\
\text { technology }\end{array}$ & $10 / 06 / 13$ & $14 / 06 / 13(+4)$ & $11 / 06 / 13(-3)$ \\
\hline D21 & $\begin{array}{l}\text { PSA announces } \\
\text { record sales in } \\
\text { Argentina }\end{array}$ & $19 / 06 / 13$ & 19/06/13 (0) & $02 / 07 / 13(+13)$ \\
\hline
\end{tabular}




\begin{tabular}{|l|l|l|l|l|}
\hline D23 & $\begin{array}{l}\text { PSA's } 3^{\text {rd }} \text { plant in } \\
\text { China }\end{array}$ & $01 / 07 / 13$ & $03 / 07 / 13(+2)$ & - \\
\hline D24 & $\begin{array}{l}\text { PSA's first half } \\
\text { 2013 results }\end{array}$ & $08 / 07 / 13$ & $11 / 07 / 13(+3)$ & $31 / 07 / 13(+20)$ \\
\hline D31 & $\begin{array}{l}\text { New president of } \\
\text { PSA }\end{array}$ & $25 / 11 / 13$ & $25 / 11 / 13(0)$ & $27 / 11 / 13(+2)$ \\
\hline
\end{tabular}

Half of the texts are released "simultaneously" (at least the same day) in FR/EN and in BR. One would actually not expect otherwise from an international company mastering its worldwide image/communication. For the other parallel releases, a little delay in the release on the Brazilian corporate website can be used as an indication of information streams. But the chronological analysis of the Argentinian releases does not allow any clear chronological priority to be established between $\mathrm{AR}$ and $\mathrm{BR}$ texts, which compromises the (possible) hypothesis that AR texts are (indirect) source texts for Brazil.

As is well-known from many historical cases in literature, no one can certify that the historical succession of given publications takes place in the same order as their production. Other factors may have an influence (the team's organization and workload for instance), not to mention the complexity of the text production (see genetic criticism and BELLEMIN-NOËL 1972). There are many reasons for extending this entire logic of chronology to translations, and even more to mass communication and international discourse.

Therefore, it is not surprising to find ambiguities in the chronology: PSA text production and diffusion circuits are international, and traditional rules are revised. This is why a closer look at the texts is needed now in order to find more evidence about the streams of communication. 


\subsubsection{Dominant French models}

Although PSA claims to work in English ${ }^{3}$ while always providing press releases in both French and English, the fact remains that Brazilian texts are much closer to French ones than to English ones, at both the syntactic and the lexical level. Any page of the corpus may illustrate this basic tendency (see one fragment in Table 6 , but many others could have been chosen).

Table 6. Syntactic and lexical comparison between Brazilian, French and English versions of PSA 2013 press release D20.

\begin{tabular}{|l|l|}
\hline Origin & Sample item D20 \\
\hline BR & $\begin{array}{l}\text { Os membros do júri salientaram em particular nesta inovação a } \\
\text { adaptabilidade do motor ao estilo de condução de cada um. O motor } \\
\text { escolhe de maneira autônoma um dos três modos de funcionamento } \\
\text { disponíveis: Zero emissão, térmico a gasolina ou misto. }\end{array}$ \\
\hline FR & $\begin{array}{l}\text { Les membres du jury ont notamment salué l'adaptabilité du moteur } \\
\text { à la conduite de chacun offerte par cette innovation. Le moteur } \\
\text { se règle de manière autonome sur un des trois modes de conduite } \\
\text { possible : zéro émission, thermique essence ou mixte. }\end{array}$ \\
\hline EN & $\begin{array}{l}\text { In particular, jury members were impressed by Hybrid Air's ability } \\
\text { to adapt to different driving styles, as the engine can select from } \\
\text { one of three modes autonomously: air power (zero emission), petrol } \\
\text { power or combined power. }\end{array}$ \\
\hline AR & $\begin{array}{l}\text { Los miembros del jurado felicitaron principalmente la adaptabilidad } \\
\text { del motor al manejo, ofrecida por esta innovación. El motor se } \\
\text { regula de manera autónoma en uno de los tres modos de manejo } \\
\text { posible: cero emisión, térmica nafta o mixta. }\end{array}$ \\
\hline
\end{tabular}

There is no evidence that AR texts, which seem to be consistently more source-oriented (using a nearly word for word replacement)

\footnotetext{
${ }^{3}$ See how Annick Kruch's (Head of PSA's corporate university) presented the situation in PSA's internal magazine in 2011 (PSAb 2011, 37): « Nous devons être capables, d'ici trois ou quatre ans, de travailler en full english » ("We must be able, within three or four years, to work in full English" - our translation).
} 
than BR ones, are used next to the FR model ${ }^{4}$. Generally speaking, no elaborate linguistic test is needed to confirm the influence of FR rather than EN or to notice that the BR translation is very source-oriented. For similar reasons, no list of illustrations will be produced to demonstrate how, in lexical terms, the same dominance of the French model is at work ${ }^{5}$.

One of the key trends underlying the relations between BR, EN, FR (and AR) texts is that the priorities in BR contrast heavily with the so-called "translation universals" (e.g. BAKER 1996), linguistic patterns that can be found in translations (such as explicitation, simplification, normalization and levelling out $)^{6}$, which happen to be marginal in our corpus. The few shifts we are able to observe in the texts are not motivated by linguistic concerns. They are much more strategic and more interesting to us, since they demonstrate power games that go on between the different entities of which the MNC consist.

What we sometimes notice is interference between languages. The strong French influence in the Brazilian subsidiary sometimes leads to awkward "interlanguage", e.g. "subida de gama" as a translation of "montée en gamme" (D8, D24) or "lançamentos através do mundo" for "à travers le monde" (D8). Some English expressions that are already part of French jargon at the management level are fully translated in BR text, e.g. "fluxo de caixa livre operacional" for "free cash flow opérationnel" (D14), and several expressions progressively migrate from English to French, then, occasionally, to Portuguese. The migration is total ${ }^{7}$ for: "flagship showroom" $\rightarrow$ "flagship" $\rightarrow$ "flagship store (espaço conceito)",

\footnotetext{
${ }^{4}$ This is why no further illustrations will be borrowed from the Argentinean website after table 6.

${ }^{5}$ Translations such as "evoluções contrastadas" for "évolutions contrastées", when "trends decidedly mixed" is used in English, are very common in the texts we analyse.

${ }^{6}$ One can notice how Pym's discussion, relating universals and norms (2008), is parallel to our methodological approach here.

${ }^{7}$ This way of importing English loanwords through the translation of French texts to Portuguese is very similar to that found in Peugeot brochures (BRUNELIÈRE, 2016).
} 
but partial for "channel mix" $\rightarrow$ "mix canal" $\rightarrow$ "composição de vendas". Such dynamics seem to be part of a new global expert language: the international model is used by "avant-garde" kernels, while more traditional areas follow along more conservatively.

\subsubsection{Tactical international marketing}

In the international press, discourse between various countries and cultures is both an unavoidable topic and, at the same time, an active agent. Like in any other international environment, when redistributing international texts, the Brazilian subsidiary makes use of clever word selections in order to upgrade its position in the company's "internal ranking" (table 7).

Table 7. Brazilian version of PSA 2013 press release D23 adds mention of Latin America to a text about China.

\begin{tabular}{|l|l|}
\hline BR & $\begin{array}{l}\text { a China é uma das três zonas de desenvolvimento prioritárias da PSA } \\
\text { Peugeot Citroën como parte de sua estratégia de internacionalização - } \\
\text { juntamente com a América Latina e a Rússia. }\end{array}$ \\
\hline FR & $\begin{array}{l}\text { PSA Peugeot Citroën a fait de la Chine l'une de ses trois zones } \\
\text { de développement prioritaires dans le cadre de sa stratégie } \\
\text { d'internationalisation. }\end{array}$ \\
\hline EN & $\begin{array}{l}\text { PSA Peugeot Citroën identified China as one of its three priority } \\
\text { development regions in its strategy of international expansion. }\end{array}$ \\
\hline
\end{tabular}

D14 is an excellent and spectacular example of deletion. Moving from FR/EN to BR, the new 308 model to be launched in Europe and announced worldwide remains fully unknown to the readers of the Brazilian website, on two occasions (one of them: Table 8). 
Table 8. voluntary omission of the new 308 model in the Brazilian PSA 2013 press release D14.

\begin{tabular}{|l|l|}
\hline BR & EN \\
\hline $\begin{array}{l}\text { o lançamento, em 2013, de } \\
\text { importantes modelos, como o Peugeot } \\
\text { 2008 em abril, o Citroën C4 Picasso } \\
\text { de 5 lugares em junho, inaugurando a } \\
\text { nova plataforma EMP2, entre outros, } \\
\begin{array}{l}\text { totalizando 17 lançamentos no ano, } \\
\text { sendo 9 na Europa. }\end{array}\end{array}$ & $\begin{array}{l}\text { Citroën C4 Picasso in June (debuting } \\
\text { the new EMP2 platform) and the new }\end{array}$ \\
$\begin{array}{l}\text { Pear will see the launch of 17 models, } \\
\text { of which 9 in Europe }\end{array}$ \\
\hline
\end{tabular}

A simple accident in terms of inattention is excluded ${ }^{8}$. Would it be a "local technical device" for maintaining sales of the current version, preventing people from postponing their purchase until the new model comes out? This example is indicative of a very selective translation process that screens the information to which readers will be given access.

\subsubsection{The autonomy of Argentinian and Brazilian subsidiaries}

In 2013, the Argentinian corporate website released: 38 "Argentinian only" documents (including 9 videos), 4 texts parallel to BR texts (already analysed in this article) and 20 texts parallel with EN/FR ones (including 9 parallel with a BR text also). Although the Brazilian and Argentinian subsidiaries are officially gathered under the AmLat (Latin America) label within PSA, with one single President, they seem to have their autonomy as far as corporate communication on websites is concerned. Although they

\footnotetext{
${ }^{8}$ In Brazil, the current version of the Peugeot 308 (produced in Argentina) was launched four years after Europe, and Brazilians have little chance to see the new version mentioned in $\mathrm{D} 14$ on their roads before a long time (hence the translation difficulty). The other vehicles mentioned are not available in Brazil (Peugeot 2008) or are already imported from Europe (C4 Picasso), and represent no "diplomatic" issue.
} 
demonstrate a strong interest in international information that can be valued at a local level, the large majority of the 109 international press releases available on the PSA's international website (more than $90 \%$, actually) remains simply ignored on the Brazilian site. Brazilian clients or investors are supposed to find information about PSA's social negotiations or strategic alliances with other companies elsewhere. This very particular understanding of what corporate communication is sheds light on the power relationship within the company, where no hegemonic presence of the headquarters can yet be felt in the subsidiary's website options.

\subsubsection{A parallel text with Brazilian origins?}

D10, dealing with the production of a new model (the 208) in Brazil presents a few characteristic features that distinguish it from the other parallel texts released on the BR and EN/FR websites. The BR text (nearly one thousand words) is much longer than the FR text (about three hundred words) and ends with the "signature paragraph" found in all "made-in-Brazil" texts. Other details confirm this first impression: quotes from an executive speech appear in full extension in the BR version, but are cut in the FR, EN and AR versions. The AR text cannot be the model, since it follows the international (FR/EN) pattern, with two noteworthy exceptions: the amount of an investment presented in Reais (why does an AR text suddenly use the Brazilian currency?) and the (voluntary) deleting of the Brazilian R\&D centre. Once again the translation is a good opportunity for the local subsidiary to filter the information. FR and EN texts give two elements of "international" information: this 208 model is also produced in three other plants worldwide (besides the Brazilian one mentioned in the BR text) and is the archetype of the "global profile vehicles" that the company intends to launch in the future (a more strategic level of discourse than the local text). When the conditions are met, in very specific cases, the local level may explain why the general stream of communication is inverted and why it imposes its own agenda on the international level. 


\subsection{Localization, a satisfactory model here?}

After having analysed the Brazilian press releases in detail, we can go back to one of our initial questions. Is localization, the process of turning a text linguistically and culturally appropriate to the target local (PYM 2004, 29), a potential model to account for the reality of PSA's production/distribution of press releases in Brazil?

The erratic distribution chronology between Argentina and Brazil and the fact that Argentina uses more texts coming from the international website contradict the "one to many" translation model which underlies the localization model. If a strong international "centre" is easy to identify, there is no clue that one (and only one) centre would be the origin of texts released in Argentina and Brazil. Argentina and Brazil can also produce texts and diffuse them (in a smaller scale). And the overall process often appears to be more of a "push" (with local subsidiaries eclectically reproducing what they like from series of texts released on the international website) than a "pull" process (i.e. a broad spectrum of texts from the international website being reproduced on many "local" websites). The most spectacular effects described in translations are related neither to linguistic nor to cultural questions, but to strategic options.

The (very few) divergences between Brazilian versions and their French models, often caused by linguistic "difficulties", indicate that the very first step of a localization process, i.e. internationalization, consisting in the removal of "the culturespecific features $[\ldots]$ in order to minimize the problems of later distributing that text to a series of locales" (idem, p. 31) has not been well treated. It would have imposed at least an "easy to translate" French model if not an English model: this is indeed one of the basic recipes of global products (cf. Walt Disney). Would the French teams not have imagined that their texts had a good chance of being used on other continents?

For a MNC, press releases cannot be treated as simple technical documents to be localized. This is precisely why they also represent 
a more interesting material for whoever wants to understand the global patterns of communication of MNCs.

\section{Summarizing: Press releases as a first step towards general patterns of global communication}

One particular article on a complex issue such as French car industries in Brazil has little chance of offering more than a starting point for TS, even if we reduce the discussion to the question of power. But a few initial questions will be hard to ignore within this particular area of study. Informational texts have a good chance, as Cronin suggests, to be representatives of "the changing relationship between translation and its markets [since] the Web leads to the breakdown of traditional divisions between technical and marketing material" (CRONIN 2003, 17). The globalized business of our contemporary world causes major changes in the way we see and practice translation (CRONIN 2003). The relationships detected in this study are probably not limited to press releases alone. Of course, larger zones and other methods will need to be explored to achieve our general goal, i.e. to understand the globalization of a MNC communication and its relationships with translation.

It has been obvious, in the many examples and text fragments taken into consideration, that the confrontation between these websites is indicative of priorities. Who decides? Why? This is a matter of norms and power relations. One of the systematic ambiguities is that source or target oriented explanations tend to reduce our contemporary worlds to either/or landscapes that may not actually be compatible with multinational companies of the size under observation. Texts produced on a Brazilian website may reflect instructions distributed via internal communication, not only when specific terminology is involved, but also when particular products cannot (yet) be mentioned. Translators, text revisers or their managers may prefer French looking concepts to fashionable English terms, or vice versa, without any direct textual 
intervention on behalf of the headquarters. Besides the general international priority, the Brazilian apparent (relative) autonomy suggests that central control from headquarters on that specific part of communication may not qualify as hegemonic.

Of course, we cannot take for granted that the kind of relationship we observed for press releases would necessarily be the same in others areas of communication (advertising, technical documents, etc.), where the headquarters, other partners or specific techniques (BRUNELIĖRE 2013) may be more influent in translation strategies. But we hope that this first accurate observation of a representative sector of the company's communication can shed light on the overall system and help us to construct hypotheses and increase our understanding of its higher levels. Our first conclusion, anyway, is the impact of many organizational complexities and situations on the verbal identity of a big multinational.

\section{References}

BAKER, M. "Corpus-based translation studies: The challenges that lie ahead." Terminology, LSP and Translation. Studies in language engineering in honour of Juan C. Sager. Ed. H. Somers. Amsterdam: Benjamins (1996): 175-186.

BRUNELIÈRE, J-F. "Formas de se referir aos funcionários em um relatório anual do setor automotivo: um estudo de corpora." In-Traduções 5, 9 (2013): 106-124.

BRUNELIÈRE, J-F. "Empréstimos em catálogos automotivos brasileiros: contribuição dos Estudos Descritivos da Tradução à compreensão do fenômeno." Fórum linguístico 13, 2 (2016): 1208-1224. 
CRONIN, M. Translation and Globalization. London \& New York: Routledge, 2003.

HERMANS, T. "Norms and the determination of translation: atheoretical framework." Translation, Power, Subversion. Eds. R. Alvarez and M. Vidal. Multilingual Matters: Clevedon, England (1996): 25-51.

HOLMES, J. (1972) "The name and nature of translation studies." Translated!: Papers on Literary Translation and Translation Studies. Ed. R. Van Den Broeck. Amsterdam: Rodopi (1988): 67-80.

International Organization of Motor Vehicle Manufacturers (OICA). World Motor Vehicle Production - World Ranking of Manufacturers - Year 2011. 2012. Available at http://oica.net/wp-content/uploads/ranking-without-china-30nov-12.pdf; accessed 14 September, 2013.

KANG, J-H. Recontextualization of news discourse: a case study of translation of news discourse on North Korea. The Translator 13, 2 (2007): 219-242.

LOGEMANN, M.; PIEKKARI, R. "Localize or local lies? The power of language and translation in the multinational corporation." Critical Perspectives on International Business 11, 1 (2015): 30-53.

ORENGO, A. Localizing News: Translation and the "Global-national" dichotomy. Language and Intercultural Communication 5, 2 (2005): 168-187.

PIEKKARI, R.; WELCH, D.; WELCH, L.; PELTONEN, J.-P.; VESA, T. "Translation behaviour: An exploratory study within a service multinational." International Business Review 22 (2013): 771-783.

PSA Peugeot Citroën (PSA). Document de référence 2012. 2013. Available at http://www.psa-peugeot-citroen.com/fr/report/161; accessed 24 August, 2013.

PSA Peugeot Citroën (PSAa). PSA PEUGEOT CITROËN Document de référence 2010. 2011. Available at http://www.psa-peugeot-citroen.com/fr/report/161; accessed 24 August, 2013. 
PSA Peugeot Citroën (PSAb). Questions à Annick Kruch. Planète, n.6. 2011. Available at https://www.yumpu.com/fr/document/view/17511417/psa-peugeotcitroen-planete-6-psa-planete-plus-psa-; accessed 14 March, 2014.

PYM, A. "On Toury's laws of how to translate." Beyond Descriptive Translation Studies. Eds. Anthony Pym, M. Shlesinger, D. Simeoni. Amsterdam \& Philadelphia: John Benjamins (2008): 311-328.

. The Moving Text:Localization, Translation, and Distribution. Amsterdam and Philadelphia: John Benjamins, 2004.

TOURY, G. Descriptive Translation Studies - and beyond. Amsterdam \& Philadelphia: John Benjamins, 1995.

. "The Nature and Role of Norms in Literary Translation." Literature and Translation: New Perspectives in Literary Studies. Eds. J. S Holmes, José Lambert, R. Van Den Broeck. Leuven: Acco (1978): 83-100.

VAN DOORSLAER, L. Translating, narrating and constructing images in journalism with a test case on representation in Flemish TV news. Meta 57,4 (2012): 1046-1059.

Recebido em: 13/04/2017

Aceito em: 06/07/2017

Publicado em setembro de 2017 